\title{
Typology of value adding FM and CREM interventions
}

\author{
Jensen, Per Anker; van der Voordt, Theo J.M.
}

Published in:

Journal of Corporate Real Estate

Link to article, DOI:

10.1108/jcre-09-2019-0042

Publication date:

2020

Document Version

Publisher's PDF, also known as Version of record

Link back to DTU Orbit

Citation (APA):

Jensen, P. A., \& van der Voordt, T. J. M. (2020). Typology of value adding FM and CREM interventions. Journal of Corporate Real Estate, 22(3), 197-214. https://doi.org/10.1108/jcre-09-2019-0042

\section{General rights}

Copyright and moral rights for the publications made accessible in the public portal are retained by the authors and/or other copyright owners and it is a condition of accessing publications that users recognise and abide by the legal requirements associated with these rights.

- Users may download and print one copy of any publication from the public portal for the purpose of private study or research.

- You may not further distribute the material or use it for any profit-making activity or commercial gain

- You may freely distribute the URL identifying the publication in the public portal

If you believe that this document breaches copyright please contact us providing details, and we will remove access to the work immediately and investigate your claim. 


\title{
Typology of Value Adding FM and CREM Interventions
}

\author{
Per Anker Jensen \\ Technical University of Denmark \\ pank@dtu.dk \\ Theo J.M. van der Voordt \\ Delft University of Technology \\ Journal of Corporate Real Estate \\ ISSN: 1463-001X, \\ https://doi.org/10.1108/JCRE-09-2019-0042 \\ Publication date: 3 February 2020
}

\begin{abstract}
Purpose - This paper presents an empirical based typology of Facilities Management (FM) and Corporate Real Estate Management (CREM) interventions that can add value to the core business of organisations and possibly the wider society. The typology is explained, elaborated and discussed with the aim to reach a deeper understanding of Value Adding Management in the context of FM and CREM.
\end{abstract}

Design/methodology/approach - The paper is based on FM and CREM literature, a survey with 15 expert interviews from six different European countries and cases with examples of interventions from earlier research.

Findings - The typology consists of six types of interventions, some mainly product related, some mainly process related and some that can be both. Each type is underpinned by examples from a case company and from interviews.

Limitations - The number of interviews is limited. The typology with related interventions is not necessarily complete. However, the typology is regarded to include the most important interventions in the current state of practice of FM and CREM.

Practical implications - The typology provides an overview of the different ways FM and CREM can add value. The cases and examples can be used as inspiration for developing specific interventions in practice.

Originality/value - The typology is the first to provide a classification of FM and CREM interventions. By integrating findings from interviews and case studies this typology contributes to a better understanding and practicing of Value Adding Management.

Keywords - Facilities Management, Corporate Real Estate Management, Added value, interventions, Typology, Value Adding Management 


\section{Introduction}

This paper is a result of a long lasting European research collaboration aiming at developing theoretical and empirical knowledge as well as guidelines for practice on how Facilities Management (FM) and Corporate Real Estate Management (CREM) can add value to organisations, individuals and society (for an overview see Van der Voordt et al., 2016). FM and CREM are two closely related and relatively new management disciplines that used to have a strong focus on controlling and reducing cost for property, workspace and related services. In recent years, there has been a change towards putting more focus on how FM/CREM can add value to the organisation.

The growing research on the added value of FM and CREM has resulted in the development of several conceptual frameworks and collection of comprehensive empirical information. However, the practical application of this knowledge has shown to be limited and difficult, mainly because the different frameworks are too complex and lack common terminology and clear operationalisations of input-output/outcome relationships (Jensen and Van der Voordt, 2017).

This paper aims to contribute to the operationalisation of the input component by presenting an empirical based typology of FM and CREM interventions. This typology includes both product and process related interventions. It has been developed as an element in a concept and model for Value Adding Management (VAM), which was presented in a recent book on FM and CREM as Value Drivers (Jensen and Van der Voordt 2017). The purpose of the paper is to explain and further elaborate the typology. Due to the growing integration of FM and CREM into FREM (Facilities and Real Estate Management, see (Van der Voordt, 2017), this typology may be of interest to both FM and CREM professionals. The paper aims to support this integration of FM and CREM and combines the two disciplines.

The theoretical background for the typology is presented in section 2 and the research methodology is explained in section 3. The typology is presented and elaborated in section 4 . The paper finishes with discussion and conclusion in chapter 5.

\section{Theoretical background}

A starting point for the research has been an investigation and comparison of four different conceptual frameworks that visualize how to add value by FM and CREM, which have been developed at European universities as part of research.

The conceptual frameworks are:

- The Finnish CREM framework by Anna-Liisa Lindholm/Sarasoja (Lindholm and Leväinen, 2006)

- The Danish FM Value Map by Per Anker Jensen (Jensen et al., 2008; Jensen, 2010)

- The Dutch CREM framework by Jackie de Vries (De Vries et al., 2008)

- The Dutch CREM framework by Alexandra den Heijer (Den Heijer, 2012) 
The first two frameworks are both inspired by strategic mapping from Balanced Scorecard methodology (Kaplan and Norton, 2001). The first version of the Finnish framework included seven real estate strategies, which can have impacts on revenue growth and/or productivity growth and thereby contribute to maximize wealth of shareholders (Lindholm and Leväinen, 2006). A second version includes sustainability as an additional real estate strategy (Jensen et al., 2012b).

The FM Value Map is based on a process model including resources as input to processes leading to FM provisions as output that can have impacts on six value parameters concerning core business and four value parameters concerning surroundings as outcome, which can have benefits for owners, staff, customer and/or society as stakeholders. Thus, one of the differences compared to the Finnish framework is that the FM Value Map includes a wider stakeholder perspective.

The framework by De Vries also includes a basic process model based on: input $\rightarrow$ process $\rightarrow$ output. In the framework of De Vries the process model is related to the overall business organisation with real estate interventions as an input, which by eight categories of influences can change performance in terms of productivity, profitability and competitive advantage. This framework, too, includes benefits for multiple stakeholders.

The framework of Den Heijer builds on the framework of De Vries, but has been redesigned in a different form and extended to include 12 value parameters and sustainable development as an additional aspect of performance. The framework of Den Heijer focuses on the organisation i.e. its policy makers, controllers, technical managers and end users.

The further development of VAM in Jensen and Van der Voordt (2017) is based on the analysis and comparison of the four conceptual frameworks mentioned above. In all four frameworks, a generic process model can be identified:

$$
\text { Input } \rightarrow \text { Throughput } \rightarrow \text { Output ---> Outcome / Added Value }
$$

An underlying cause-effect model included in all the four conceptual frameworks with different wordings can also be identified as shown in Table 1 .

Table 1. Cause-effect model in the four conceptual frameworks

\begin{tabular}{|l|l|l|}
\hline Framework & Cause & Effect \\
\hline Lindholm/Sarasoja & Real estate decisions and operations & Added Value \\
\hline Jensen & Provisions & Impact (Outcome) \\
\hline De Vries & Real estate interventions & Influence/Performance \\
\hline Den Heijer & Real estate projects & Performance (Output) \\
\hline
\end{tabular}

Jensen et al. (2012a) define added value as 'the trade-off between benefits and sacrifices', where sacrifices cover cost and risk. One of the essential lessons learned from the earlier research on added value is that adding value need to be managed and linked to the mission, vision and objectives of the involved organization. Interventions in FM and CREM will always have 
consequences, but to ensure a positive impact on the organisation, the interventions need to be managed in a proper and professional way (Jensen and Van der Voordt, 2017).

The concept of Value Adding Management was introduced in a FM context by Jensen and Katchamart (2012). The focus was on the relationships between FM and the core business at strategic, tactical and operational levels and it was argued that the relationships with the stakeholders should be managed differently at each level.

By replacing input by intervention and including management as the intermediary process between cause and effect, a generalised model for VAM can be defined:

$$
\text { Intervention } \rightarrow \text { Management } \rightarrow \text { Added Value }
$$

This model is very simple and combines essential aspects of the different conceptual frameworks supplemented with the management of implementing the intervention to ensure that the FM/CREM interventions lead to added value for the organisation. An extended version of the VAM model that is integrated with the Plan-Do-Check-Act circle, is included in Van der Voordt et al. (2016) and Jensen and Van der Voordt (2017).

The purpose of this paper is to present, elaborate and discuss the first part of the VAM model called 'Intervention'. The term 'intervention' is in this context understood as actions leading to changes in the process or the products provided by FM and CREM with the aim to add value. An elaboration of the final part of the model i.e. how to check whether the interventions has resulted in added value can be found in Van der Voordt and Jensen (2018).

\section{Methodology}

In order to explore how people in practice work with added value and what interventions they have experience with, 15 semi-structured interviews were conducted with senior facility managers, corporate real estate managers, consultants and service providers from Europe. An initial survey included 11 interviews with five interviewees from Denmark (DK) and six from the Netherlands (NL). The interviews from Denmark and the Netherlands were supplemented to provide a broader European foundation by four interviews with FM/CREM experts from Austria (A), Norway (N), Spain (E) and Sweden (S), see Table 2. Results from the initial survey were presented in a conference paper (Van der Voordt and Jensen, 2014), which did not include the typology. Summaries of 12 of the interviews are published in Jensen and Van der Voordt (2017).

The criteria for selection were that the interviewees should have senior level of practical experience and represented a mix of FM and CREM professionals as well as a mix of in-house FM, service providers and consultants. All interviewees were from the private sector. The final sample represented companies from various industries such as biotechnology, FM consulting, facilities services, technical services, workplace consulting and care insurance, and functions such as director for FM and/or CREM, division director, managing director and owner. Years of experience ranged from 10 to 34 years. 
Table 2: List of interviewees

\begin{tabular}{|l|l|l|l|}
\hline Country & Role & Company & Function \\
\hline A & Consultant & FM consulting & Managing Director \\
\hline DK & In-house & Biotechnology & Director and Facilities Manager \\
\hline DK & Consultant & FM consulting & Owner \\
\hline DK & Consultant & FM consulting & Owner \\
\hline DK & Provider & Facilities services & Division Director \\
\hline DK & Provider & Facilities services & Managing Director \\
\hline E & Provider & Facilities services & Global Senior Project Manager \\
\hline N & Consultant & FM consulting & Owner \\
\hline NL & In-house & Technical services & Corporate Real Estate Manager \\
\hline NL & Consultant & Real estate consulting & Owner \\
\hline NL & Consultant & Workplace consulting & Owner \\
\hline NL & Consultant & Real estate consulting & Owner \\
\hline NL & In-house & Care insurance & Director of Real Estate and FM \\
\hline NL & In-house & ICT-services & Real Estate Manager \\
\hline S & In-house & Mobile communication & Global Head of FM \\
\hline
\end{tabular}

The interview guide included a number of questions regarding the use of the term 'Added Value' in daily practice, in which context or dialogue, on which levels (strategic, tactical, operational), benefits and downsides of using 'Added Value' in interactions between different actors and Top 5 of highest prioritized values. Other questions concerned examples of concrete FM/CREM interventions, ways of measuring (KPIs) and documentation, and if/how benchmarking is applied in practice.

The typology was developed by analysing the interventions mentioned by the interviewees in connection with FM/CREM literature and cases from earlier research. For this paper, a case study suitable to illustrate each type of intervention was selected.

\section{The typology}

The typology consists of the following six types of FM and CREM interventions:

1. Changing the physical environment (on different scale levels: portfolio, building, space)

2. Changing facilities services

3. Changing the supply chain

4. Changing the internal processes

5. Changing the interface with core business

6. Changing strategic advice and planning

The two first types of interventions concern changes in what FM and CREM provides in relation to the physical environment and facilities services . Thus, they are both product related. The next two types of interventions concern changes in how FM and CREM provides in relation to the 
supply chain and internal processes . Thus, they are both process related. Furthermore, changes in the supply chain also involve who is responsible for the provision. The last two types of interventions can be either product or process related, or a combination.

Interventions concerning changes in the interface with core business (type 5) can involve changes in the scope of FM/CREM as shown in case 5 in section 4.5. This results in changes in what is provided, Such interventions are product related. However, changes in the interface with core business can also concern communication and information channels and thereby changes in the interaction between FM/CREM and core business, for instance by implementing a helpdesk, introducing satisfaction surveys and use of social media in the communication with users. Such interventions are process related. Interventions concerning strategic advice (type 6) can similarly concern what projects or contracts should be developed, which is product related, and how projects and contracts should be developed, which is process related.

All interviewees were asked an open question about their Top 5 prioritized values and to specify concrete interventions to attain each value. However, the number of values and interventions varied among the interviewees. Altogether 55 interventions were mentioned equivalent to 3.9 in average per interview. These interventions were used to develop the typology and classified by the researchers according to the developed typology. The results are shown in Table 3.

Table 3. Interventions mentioned in interviews

\begin{tabular}{|l|c|c|c|c|}
\hline Type of intervention & Denmark & Netherlands & Others & Total \\
$\mathbf{4}$ & $\mathbf{6}$ & 6 & 4 & 12 \\
\hline 1, Changing the physical environment & 2 & 4 & 7 & 16 \\
\hline 2. Changing facilities services & 5 & 0 & 0 & 2 \\
\hline 3. Changing the supply chain & 2 & 3 & 6 & 10 \\
\hline 4. Changing the internal processes & 1 & 0 & 0 & 0 \\
\hline 5. Changing the interface with core business & 0 & 6 & 3 & 15 \\
\hline 6. Strategic advice and planning & 6 & $\mathbf{1 9}$ & $\mathbf{2 0}$ & $\mathbf{5 5}$ \\
\hline Sum & $\mathbf{1 6}$ & &
\end{tabular}

The most mentioned interventions concerned Changing the facilities services (16) followed by Strategic advice and planning (15), Changing the physical environment (12) and Changing the internal processes (10), There were surprisingly few examples of interventions concerning Changing the supply chain (2), and there were no examples of interventions concerning Changing the interface with core business. These results are supported by recent findings from Udawatta et al. (2019), who found changing the physical environment, changing the facilities services and strategic advice and planning to be the most acceptable interventions in semi-structured interviews with three experienced industry experts in Sri Lanka.

The data were also analysed quantitatively in relation to the type of organisation the interviewees worked, divided in in-house FM/CREM functions, providers and consultants. The results are shown in Table 4. The interviewees were distributed with five in-house, three providers and seven 
consultants. The most even distribution on the different interventions was seen for in-house with the most frequent being Changing the facilities services (5) and Strategic advice and planning (5). Providers mostly focused on Changing the facilities services (4) and Changing the internal processes (4), which is not surprising. Consultants mostly focused on Changing the physical environment (9), Strategic advice and planning (9) and Changing the facilities services (7).

Table 4. Interventions distributed according to type of organisation

\begin{tabular}{|l|c|c|c|c|}
\hline Type of intervention & In-house & Provider & Consultants & Total \\
\hline 1, Changing the physical environment & $\mathbf{5}$ & $\mathbf{3}$ & $\mathbf{7}$ & $\mathbf{1 5}$ \\
\hline 2. Changing facilities services & 3 & 0 & 9 & 12 \\
\hline 3. Changing the supply chain & 5 & 4 & 7 & 16 \\
\hline 4. Changing the internal processes & 2 & 0 & 0 & 2 \\
\hline 5. Changing the interface with core business & 0 & 4 & 2 & 10 \\
\hline 6. Strategic advice and planning & 5 & 0 & 0 & 0 \\
\hline Sum & $\mathbf{1 9}$ & $\mathbf{9}$ & $\mathbf{2 7}$ & 15 \\
\hline
\end{tabular}

In the following six sub-sections, each type of intervention is presented together with examples from a case company based on earlier research as well as all examples of interventions from the 15 interviews.

The respondents from practice often mixed values with objectives, interventions and comments, for instance regarding cost reduction saying: 'Space management is key. Cost reduction by FM is more difficult: slower, more painful, less improvement (e.g. less cleaning, less catering)'. Besides, the interviewees expressed values in many different terms. When appropriate we sometimes slightly adapted their responses to fit better with the columns in tables 5 and 7-10.

Some interviewees mentioned an objective or value and KPIs without including interventions. For instance Business Alignment can be measured by surveys on how customers experience end products and services and by management by walking around (observation, talking, getting a sense of what's going on). Cost effectiveness can be measured by $€$ per $\mathrm{m}^{2}$, per person, per service or activity; and by benchmarking or dialogues (internal or with experts from other organizations). However, responses without interventions have been excluded from the tables.

Additional comments have been excluded as well, for instance "We look continuously at maximising flexibility as well as optimising total cost of occupancy and risk avoidance in connection with investment costs. Branding and identity are important, but keeping in mind that exclusive-looking buildings are perceived by customers as too expensive and a waste of (our) money. Sustainability is becoming more important but is not prioritised clearly at this stage of its evolution, and is mainly focused on industrial products rather than on buildings.” 


\subsection{Changing the physical environment}

The physical environment includes buildings, internal and external spaces, technical services (installations), indoor climate, fitting out, furniture, workplaces, technology, artwork and ambience, interior design of furniture, floor and wall finishing and kitchen attributes. For CREM, the main focus is on acquisition, development of real estate and management of buildings-in-use, while for FM the main focus is on supporting workplaces, development of working environments, and delivery of services such as reception, catering, cleaning, and ICT.

Typical examples of changing the physical environment include:

- Moving to another location (new or existing building), see example in Case 1

- New building

- Rebuilding, refurbishment or adaptive re-use i.e. conversion to new functions

- Changing workplace layout, e.g. conversion of a cellular office with personal desks to an activity-based work setting with shared use of a variety of task-related workspaces.

- Changing appearance ('look and feel')

Case 1. Philips' move from Eindhoven to Amsterdam (Hoendervanger et al., 2012) Before the Second World War, the Philips corporation was accommodated in a number of different buildings scattered in the south of the Netherlands. Due to organisational changes, globalisation, technological developments and the move of work to low income countries, the demand for space has drastically changed in the last decades. In the early nineties Philips started the so-called 'Centurion Operation'. Almost all locations in Eindhoven were closed or moved or became independent. The headquarters was moved from Eindhoven to Amsterdam, because of a closer distance to Schiphol Airport and the central location in one of the most important financial districts of the Netherlands.

This move evoked much resistance among the Eindhoven municipality, due to loss of employment and municipal income, and the damage to the image of Eindhoven as one of the most important centres of industrial knowledge. The labour unions complained about the loss of jobs and the high costs in a period of heavy cutbacks. Nevertheless, the Executive Board persevered, because they wanted to be located in what they perceived as a Centre of Competence. About 500 employees have been accommodated in the Breitner Tower in Amsterdam. The 23 storeys are equipped with high tech facilities regarding control of access, lighting, ventilation and energy saving.

This case shows that the added value of a move can be perceived very different for different stakeholders.

The 12 interventions concerning changing the physical environment mentioned in interviews are listed in Table 5 together with the prioritized value each intervention was related to and the KPIs used to measure the value according to the interviewees. 
Table 5. Interventions concerning changing the physical environment mentioned in interviews

\begin{tabular}{|c|c|c|}
\hline Intervention & Prioritized value & KPIs (fte = full time equivalent) \\
\hline $\begin{array}{l}\text { Ongoing focus on space utilization } \\
\text { by appropriate space management, } \\
\text { desk-sharing and flexible use of } \\
\text { activity-based workplaces }\end{array}$ & $\begin{array}{l}\text { Core business objectives } \\
\text { Cost reduction }\end{array}$ & $\begin{array}{l}\text { Less } \mathrm{m}^{2} \text {, less movements, } \\
\text { lower costs by less building } \\
\text { adaptations }\end{array}$ \\
\hline Reduce $\mathrm{m}^{2}$ (most important) & Cost reduction & Less $\mathrm{m}^{2}$, less cost $/ \mathrm{m}^{2}$ \\
\hline $\begin{array}{l}\text { Reduce costs and length of rental } \\
\text { contracts }\end{array}$ & Cost reduction & $€ / \mathrm{m}^{2}, € /$ workplace \\
\hline Reduce cost $/ \mathrm{m}^{2}$ & Cost reduction & $\begin{array}{l}\text { Cost } / \mathrm{m}^{2} \text {, cost } / \mathrm{fte} \text { (depends } \\
\text { on product) }\end{array}$ \\
\hline $\begin{array}{l}\text { Standardise } \mathrm{m}^{2} / \text { work place and } \\
\mathrm{m}^{2} / \mathrm{fte}\end{array}$ & $\begin{array}{l}\text { Efficient use of space and } \\
\text { other facilities (cost } \\
\text { reduction) }\end{array}$ & $\mathrm{m}^{2} /$ workplace and $\mathrm{m}^{2} / \mathrm{fte}$ \\
\hline $\begin{array}{l}\text { Reduce the size of work desks to } \\
\text { create more workplaces, more } \\
\text { intense communication and less } \\
\text { paper mess. }\end{array}$ & Innovation & Not mentioned \\
\hline $\begin{array}{l}\text { Dispose of real estate to gain cash } \\
\text { (depends of book value, local market } \\
\text { etc.). Sale and Lease back } \\
\text { No 'cheese slicer' approach: } \\
\text { disposal of one floor is not } \\
\text { interesting; focus is on whole } \\
\text { locations/buildings }\end{array}$ & $\begin{array}{l}\text { Profit (Ebit); improving } \\
\text { cash position }\end{array}$ & $\begin{array}{l}\text { Impact of lower real estate } \\
\text { costs on profit } \\
\text { Footprints per region }\end{array}$ \\
\hline $\begin{array}{l}\text { Choice of materials, e.g. Cradle-to- } \\
\text { Cradle floor and wall finishing and } \\
\text { furniture } \\
\text { Being able to recycle }\end{array}$ & Sustainability & $\begin{array}{l}\text { Often not really measured } \\
\text { (due to costs of measuring) }\end{array}$ \\
\hline Reduce noise & (Not mentioned) & Absence due to sickness \\
\hline $\begin{array}{l}\text { Ensure optimal chairs (office, crane, } \\
\text { machine, truck) }\end{array}$ & Health and wellbeing & Long-term health \\
\hline $\begin{array}{l}\text { Improve climate comfort by optimal } \\
\text { heat, humidity and air change rate }\end{array}$ & $\begin{array}{l}\text { Employee satisfaction } \\
\text { and wellbeing }\end{array}$ & Absence due to sickness \\
\hline $\begin{array}{l}\text { Reduce risk by life cycle focus and } \\
\text { improved asset management }\end{array}$ & Risk reduction & $\begin{array}{l}\text { All together } 8 \text { KPI's divided } \\
\text { in } 4 \text { groups: Quality, cost, } \\
\text { innovation and incidents }\end{array}$ \\
\hline
\end{tabular}




\subsection{Changing facilities services}

The facilities services are operational activities. In the European standard on taxonomy for FM, facilities services are divided in Space \& Infrastructure and People \& Organisation with both categories sub-divided in standardised facility products as shown in Table 6.

Table 6. FM taxonomy with standardised facility products (CEN, 2011)

\begin{tabular}{|l|l|}
\hline Demand related to & Standardised facility product \\
\hline \multirow{5}{*}{ Space \& Infrastructure } & Space (Accommodation) \\
\cline { 2 - 2 } & Outdoors \\
\cline { 2 - 2 } & Cleaning \\
\cline { 2 - 2 } & Workplace \\
\cline { 2 - 2 } & Primary activities specific \\
\hline \multirow{5}{*}{ People \& Organisation } & HSSE (Health, Safety, Security \& Environment) \\
\cline { 2 - 2 } & Hospitality \\
\cline { 2 - 2 } & ICT (Information and Communication Technology) \\
\cline { 2 - 2 } & Logistics \\
\cline { 2 - 2 } & Business Support (Management Support) \\
\cline { 2 - 2 } & Organisation specific \\
\hline
\end{tabular}

Table 6 only includes the operational products at the top level. Each of the standardised facility products are sub-divided in up to two more levels. The taxonomy is based on a life cycle perspective of the products. This is of particular importance for the first product called Space (Accommodation). This covers both acquisition and development of buildings (in the taxonomy divided in the sub-products Building initial performance, Asset replacement and refurbishment, Enhancement of initial performance, and Portfolio development) as well as daily operation of buildings (in the taxonomy divided in the sub-products Property administration, Maintenance and operation, and Utilities). The Space sub-products related to acquisition and development of buildings are very CREM related and covered by the above mentioned interventions related to changing the physical environment. The other Space sub-products are more related to changing facilities services.

An example of research on hospitality in a FM context is presented in case 2.

Case 2: Hospitality in hospital facilities (Groen, 2014)

A Dutch research project involving three hospitals in the Netherlands explored what aspects of a hospital stay are related most to hospitality according to the patients. The study adopts a definition of hospitality, which refers to a host that provides security, psychological and physical comfort for a guest, who is away from home, the coming together of a provider and receiver, and a blend of tangible and intangible factors. Hospitality serves as a means for the host and the guest to protect both from hostility. The study secondly builds on a definition of hospitality as a contemporaneous human exchange, which is voluntarily entered into, and designed to enhance the mutual wellbeing of the parties concerned through the provision of accommodation and food or drink. Thirdly, the 
study adopts the four dimensions of hospitality: spatial, temporal, behavioural, and physical. Many of the tangible factors (accommodation, food and drink, cleanliness) are taken care of by FM, whereas the dimensions attitude and behaviour refer to both FM and medical staff.

The results showed that taking adequate time, listening, involvement and quality of care were associated most frequently with hospitality. Within the behavioural dimension, patients valued 'being taken care of' highest. They want to be set at rest, reassured, and set at ease. Aspects of space and facilities were also mentioned, but less often, mainly referring to the availability of coffee in waiting areas, and adequate spaces, also for people in wheelchairs or walkers.

The case revealed some particularity of hospitality in a hospital environment compared with similar research from hospitality industry (hotels etc.) (Groen, 2014).

Typical examples of interventions related to the other People \& Organisation related products ICT (Information and Communication Technology), Logistics and Business Support are:

- Changing the ICT services by introducing new software solutions, new mobile solutions and/or improved IT end user services with increased responsiveness by support staff and training of particular users

- Changing the handling of post to become more digital by introducing electronic document handling system, scanning technology and archiving services

The 16 interventions concerning changing the facilities services mentioned in interviews are listed in Table 7.

Table 7. Interventions concerning changing the facilities services mentioned in interviews

\begin{tabular}{|l|l|l|}
\hline Intervention & Prioritized value & KPIs \\
\hline $\begin{array}{l}\text { Waste handling } \\
\text { Use of materials } \\
\text { Handling of chemicals }\end{array}$ & $\begin{array}{l}\text { Corporate Social } \\
\text { Responsibility (CSR) }\end{array}$ & $\begin{array}{l}\text { Energy consumption. } \\
\text { Water consumption } \\
\text { Emission of } \mathrm{CO}_{2}\end{array}$ \\
\hline $\begin{array}{l}\text { Meeting facilities that are ready to } \\
\text { use, in order to create time. } \\
\text { Release the core business staff of } \\
\text { having to spend time or effort on } \\
\text { support related tasks, which the FM- } \\
\text { is better suited to carry out }\end{array}$ & $\begin{array}{l}\text { Productivity } \\
\text { Satisfaction }\end{array}$ & User satisfaction \\
\hline $\begin{array}{l}\text { Good food and coffee in the canteen } \\
\text { Make good working conditions with } \\
\text { attractive work environment and } \\
\text { internal services }\end{array}$ & Create well-being & User satisfaction \\
\hline $\begin{array}{l}\text { Delivery of high quality facilities } \\
\text { and services to retain staff } \\
\text { Leadership } \\
\text { Social innovation }\end{array}$ & $\begin{array}{l}\text { Engagement / commitment } \\
\text { to the company }\end{array}$ & $\begin{array}{l}\text { Audits (surveys) by HR } \\
\text { (e.g. is work environment } \\
\text { inspiring?) }\end{array}$ \\
\hline
\end{tabular}




\begin{tabular}{|c|c|c|}
\hline $\begin{array}{l}\text { Stimulate to take the staircase } \\
\text { Healthy food }\end{array}$ & Health & $\begin{array}{l}\text { Sick leave } \\
\text { Health complaints }\end{array}$ \\
\hline $\begin{array}{l}\text { Digitization of all documents -> } \\
\text { improved efficiency; new ways of } \\
\text { working -> better working climate - } \\
\text { > improved indoor air quality and } \\
\text { comfort > ditto }\end{array}$ & $\begin{array}{l}\text { Improving core business / } \\
\text { productivity }\end{array}$ & $\begin{array}{l}\text { Measuring activities: by } \\
\text { whom, when; measuring } \\
\text { workplace occupancy } \\
\text { Many issues not really } \\
\text { measured, mainly } \\
\text { discussed e.g. new ways } \\
\text { of working -> better } \\
\text { private life }\end{array}$ \\
\hline $\begin{array}{l}\text { Giving choices, for instance in } \\
\text { catering } \\
\text { User centricity and service } \\
\text { orientation }\end{array}$ & $\begin{array}{l}\text { User satisfaction } \\
\text { Customer satisfaction }\end{array}$ & $\begin{array}{l}\text { User surveys } \\
\text { Exit polls } \\
\text { Mystery visits }\end{array}$ \\
\hline Friday morning brunch & User satisfaction & $\begin{array}{l}\text { Peoples Opinion } \\
\text { (External measurements) }\end{array}$ \\
\hline $\begin{array}{l}\text { Better person to person services, e.g. } \\
\text { by bringing lost item to workstations } \\
\text { and bringing food into a meeting }\end{array}$ & $\begin{array}{l}\text { User satisfaction } \\
\text { Customer satisfaction }\end{array}$ & $\begin{array}{l}\text { Customer satisfaction } \\
\text { Reduction of complaints }\end{array}$ \\
\hline $\begin{array}{l}\text { Reprogramming/optimising of } \\
\text { elevators } \\
\text { Removal of noticeable barriers }\end{array}$ & Productivity & $\begin{array}{l}\text { Productivity measures } \\
\text { Output (e.g. call centre) }\end{array}$ \\
\hline Scaling up and down & Flexibility & \multirow{2}{*}{$\begin{array}{l}\text { All together } 8 \text { KPI's } \\
\text { divided in } 4 \text { groups: } \\
\text { Quality, cost, innovation } \\
\text { and incidents }\end{array}$} \\
\hline $\begin{array}{l}\text { Co-creation by developing new } \\
\text { services and app’s together with } \\
\text { suppliers to sell to customers }\end{array}$ & $\begin{array}{l}\text { Productivity } \\
\text { Customer satisfaction }\end{array}$ & \\
\hline $\begin{array}{l}\text { Close tenant/user follow-up based on } \\
\text { firm information and understanding } \\
\text { of their primary activities and } \\
\text { associated accommodation and } \\
\text { service needs }\end{array}$ & $\begin{array}{l}\text { Image i.e. reputation for } \\
\text { high quality tenant } \\
\text { User satisfaction }\end{array}$ & $\begin{array}{l}\text { Satisfaction indexes } \\
\text { (client, tenant, user) } \\
\text { Quality/quantity scores } \\
\text { on estimated/agreed } \\
\text { requirements/targets in } \\
\text { each relevant service } \\
\end{array}$ \\
\hline $\begin{array}{l}\text { Different intervention for client and } \\
\text { users to ensure the right level of } \\
\text { satisfaction and identify } \\
\text { improvement areas } \\
\text { Clients: consistent governance } \\
\text { process } \\
\text { User: fluent feedback of their } \\
\text { perception of services }\end{array}$ & Customer Satisfaction & $\begin{array}{l}\text { \% of satisfaction in } \\
\text { different and periodical } \\
\text { surveys for users, } \\
\text { customers and client } \\
\text { leadership }\end{array}$ \\
\hline $\begin{array}{l}\text { Produce an integrated HSEQ plan } \\
\text { and business continuity plan for all } \\
\text { services provided adapted to the } \\
\text { specificities of the client core } \\
\text { activities onsite, to ensure } \\
\text { compliance and the best level HSEQ }\end{array}$ & $\begin{array}{l}\text { HSEQ - Health, Safety, } \\
\text { Environment, Quality }\end{array}$ & $\begin{array}{l}\text { Number and severity of } \\
\text { incidents } \\
\text { Level of outputs from } \\
\text { regulatory audits. }\end{array}$ \\
\hline
\end{tabular}




\begin{tabular}{|l|l|l|}
\hline $\begin{array}{l}\text { Managing of optimal service, e.g. if } \\
\text { a client does travel but does not have } \\
\text { a travel insurance they send a mail to } \\
\text { remind them }\end{array}$ & $\begin{array}{l}\text { Positive experience by } \\
\text { customers }\end{array}$ & (Not mentioned) \\
\hline
\end{tabular}

\subsection{Changing the supply chain}

FM is in most cases organised as a mixture of an in-house FM-function and a number of external providers of facilities services, which constitutes a FM supply chain. The situation is to some degree similar for CREM, but the CREM supply chain is more project-related and mostly consists of consultants, designers and contractors. Changes in the supply chain are primarily changes in the delivery process, but they often also have consequences for the incentives for the different parties and the management of the mutual relationships between the parties.

The number of external providers varies a lot depending on the type of company and the sourcing strategies. Outsourcing in FM has over the last decades been constantly increasing in most countries and is a common way to achieve cost reductions in FM. Out-tasking of single services to different providers working in parallel for the same company has earlier been dominating, but outsourcing of bundled services has become more common. Integrated Facilities Services contracts (I-FS), where one external provider is responsible for all or most facilities services as well as management, is not unusual today, particularly among multinational companies. The benefits of integrated contracts are often argued as synergies between different services, more professional management of the service provision and less need of in-house management resources. For I-FS this is typically supplemented by one point of contact between the customer company and the provider. Even though the general trend is towards more outsourcing in most countries, there are also many examples of insourcing of former outsourced services (Jensen, 2017). Case 3 shows examples of changes in the supply chain involving insourcing as well as outsourcing.

Case 3. Changing responsibilities in the supply chain (Jensen and Malmstrøm, 2012) A case from the Swedish based service provider Coor Service Management provides examples of changes in responsibility from in-house to the external service provider. Regarding the provision of work wear, the responsibility was taken over by the service provider, who reorganised the work process. Consequently, the internal employees were relieved to do other work for the core business. Regarding deliveries for hospital wards the responsibility for ordering and receiving deliveries were transferred to the service provider, who involved dedicated and trained staff to do the work. The nurses and other internal staff were relieved to do their healthcare core business work.

Transfer of responsibility from in-house is an essential element in outsourcing. However, the example was not part of an outsourcing process involving tendering and transfer of staff, but part of on-going collaboration between provider and client.

The two interventions concerning changing the supply chain mentioned in interviews are listed in Table 8. 
Table 8. Interventions concerning changing the supply chain mentioned in interviews

\begin{tabular}{|l|l|l|}
\hline Intervention & Prioritized value & KPIs \\
\hline $\begin{array}{l}\text { Outsource all operational services } \\
\text { Release management resources, so } \\
\text { that line of business can focus on } \\
\text { their core tasks. }\end{array}$ & Productivity & $\begin{array}{l}\text { Follow up on FM } \\
\text { suppliers from Sourcing } \\
\text { and FM }\end{array}$ \\
\hline $\begin{array}{l}\text { Long-term relation / partnership with } \\
\text { key FM suppliers and a } \\
\text { "Management by Exceptions" } \\
\begin{array}{l}\text { concept: Reduce the needs for } \\
\text { detailed control on daily business. }\end{array}\end{array}$ & $\begin{array}{l}\text { Satisfaction with service } \\
\text { providers }\end{array}$ & $\begin{array}{l}\text { Key figures for price, } \\
\text { quality and user } \\
\text { satisfaction. Monthly, } \\
\text { quarterly and yearly } \\
\text { follow up at different } \\
\text { management levels. }\end{array}$ \\
\hline
\end{tabular}

\subsection{Changing the internal processes}

The aim of changing the internal processes usually is to increase the efficiency of operational processes within a specific organisation without necessarily changing neither the product, nor the supply chain. The organisation can be in-house or an external provider. Within management theory and practice, there are a number of concepts aimed at increasing productivity and process efficiency, for instance Total Quality Management, Business Process Engineering, Benchmarking and Lean Management. Typical elements in such concepts are eliminating waste, implementing new technological solutions and optimising the workflow. Many companies conduct projects by using such concepts and the FM function is often included in the project. Many provider companies also work systematically with developing process innovations and this is also the case for some of the larger in-house organisation.

A common way to change the internal services is to create synergy between services. An example is to change part time jobs to full time jobs for instance by combining cleaning in early morning with catering later during the day. Thereby the number of service staff and cost can be reduced, flexibility increased, and work perhaps enriched. An example of multiskilling of FM staff is presented in Case 4.

Case 4. Multiskilling of FM staff in Copenhagen Airport (Jensen et al., 2008) At Copenhagen Airport, the FM department has worked systematically with multiskilling of their service staff. An important activity in the airport during wintertime is snow clearing of runways etc., which is difficult to predict and needs a lot of work force immediately for short periods. Therefore, they have trained much of the service staff to be qualified to operate the snow clearing equipment as a task besides their usual job in periods when needed.

The case shows that multiskilling creates flexibility for the airport, but the FM manager also argued that it provides higher value on the labour market for the staff. 
The 10 interventions concerning changing the internal processes mentioned in our interviews are listed in Table 9.

Table 9. Interventions concerning changing the internal processes mentioned in interviews

\begin{tabular}{|c|c|c|}
\hline Intervention & Prioritized value & KPIs \\
\hline $\begin{array}{l}\text { Express being sustainable } \\
\text { Improve image of FM department, } \\
\text { e.g. by improving recognisability of } \\
\text { FM staff by appropriate clothing }\end{array}$ & Identity (image) & $\begin{array}{l}\text { Monitoring image of FM } \\
\text { department, internally } \\
\text { (employee monitor) and } \\
\text { external (customer monitor) }\end{array}$ \\
\hline $\begin{array}{l}\text { Make processes smarter by best } \\
\text { practice sharing }\end{array}$ & Cost reduction & $\begin{array}{l}\text { Cost measures } \\
\text { Response times }\end{array}$ \\
\hline $\begin{array}{l}\text { Reduce cost } \\
\text { More for less }\end{array}$ & Cost optimization & $\begin{array}{l}\text { Budget vs. spend at local, } \\
\text { regional and global level } \\
\text { Account payable (invoiced } \\
\text { and paid) } \\
\text { User satisfaction (related to } \\
\text { optimisation) }\end{array}$ \\
\hline $\begin{array}{l}\text { Service Navigator, an example from } \\
\text { the I-FM provider with a new way } \\
\text { of organising FM services with a } \\
\text { multi-skilled person servicing a } \\
\text { floor of a building }\end{array}$ & Innovation & $\begin{array}{l}\text { Buyer satisfaction (FM and } \\
\text { procurement) } \\
\text { Supplier satisfaction (I-FM } \\
\text { provider) } \\
\text { User satisfaction }\end{array}$ \\
\hline $\begin{array}{l}\text { Reliable sourcing and procurement } \\
\text { processes } \\
\text { Environmental sustainability }\end{array}$ & $\begin{array}{l}\text { High reputational } \\
\text { profile on ethics, social } \\
\text { responsibilities (image } \\
\text { and identity) }\end{array}$ & $\begin{array}{l}\text { Reputation surveys scores } \\
\text { Different energy scores } \\
\text { (selection/configuration of } \\
\text { energy sources, efficiency } \\
\text { etc.) }\end{array}$ \\
\hline $\begin{array}{l}\text { Ensure cost reduction, traceability, } \\
\text { accuracy and standardization of } \\
\text { reporting }\end{array}$ & $\begin{array}{l}\text { Financial value (Cost } \\
\text { Reduction) }\end{array}$ & $\begin{array}{l}\text { Budget accuracy } \\
\text { Savings materialised } \\
\text { Invoicing and reporting } \\
\text { accuracy }\end{array}$ \\
\hline $\begin{array}{l}\text { Share benchmarking and best } \\
\text { practices across sites and contracts, } \\
\text { to demonstrate know-how, best } \\
\text { practices implementation and } \\
\text { continuous improvement }\end{array}$ & Innovation & $\begin{array}{l}\text { Number and impact of } \\
\text { innovations proposed }\end{array}$ \\
\hline $\begin{array}{l}\text { Produce an Operating Manual with } \\
\text { the key elements to integrate and } \\
\text { manage the services in scope, in } \\
\text { order to ensure compliance with the } \\
\text { level of quality agreed in each } \\
\text { service }\end{array}$ & $\begin{array}{l}\text { Service and asset } \\
\text { performance }\end{array}$ & $\begin{array}{l}\text { Outputs from monthly service } \\
\text { audits } \\
\text { Availability of assets } \\
\text { Service continuity }\end{array}$ \\
\hline
\end{tabular}




\begin{tabular}{|l|l|l|}
\hline $\begin{array}{l}\text { Education and training regarding } \\
\text { cognitive skills, professional } \\
\text { knowledge and skills, and leadership } \\
\text { skills }\end{array}$ & $\begin{array}{l}\text { Professionalism of } \\
\text { FM/CREM staff }\end{array}$ & (Not mentioned) \\
\hline $\begin{array}{l}\text { Digitization/ logistics of document } \\
\text { management and using LEAN Six } \\
\text { Sigma principles }\end{array}$ & $\begin{array}{l}\text { Working together on } \\
\text { success in an efficient } \\
\text { way }\end{array}$ & $\begin{array}{l}\text { Analysis of whole supply } \\
\text { chain }\end{array}$ \\
\hline
\end{tabular}

\subsection{Changing the interface with core business}

When organisations reach a certain size and complexity FM and CREM are typically established as separate functions. The interface between the core business and FM/CREM is defined specifically in each organisation and is not static. If the FM/CREM function is successful, it might get the opportunity from top management to increase its area of responsibility. This is often part of a centralisation of the responsibility from several parts of the core business organisation to the FM/CREM function. An example of changes in this interface is presented in Case 5.

Case 5. Changes in responsibilities (Jensen and Malmstrøm, 2012)

A case from the Danish pharmaceutical company Lundbeck shows an example of a change in responsibility between the core business and the in-house FM unit concerning the management of internal moving. Earlier the departments that needed to move staff had to contact the different service units responsible for ordering handy-men to move furniture, rearranging phone connections, reorganising IT equipment and connections and updating signage. Instead, the FM unit offered a new streamlined moving process, where they provided a one stop ordering process on the company intranet and took care of the coordination of all the services involved in an internal move of staff. This meant that the coordination of the necessary tasks was transferred from the core business department to the FM unit.

This case is an example of a typical service management product innovation, which relieves the customers from trivial tasks and implements a smooth service delivery with increased speed and making the organisation more flexible. Other examples of service innovation in FM are presented by Nardelli (2017) and Nardelli and Broumels (2018).

Changes in communication and information channels and procedures are typical areas, where FM and CREM can change the interface between the core business and the support function and become more proactive rather than reactive. For instance, the cleaning staff or the security staff, who during their work gets around to most rooms in a building, could be asked to report any faults like non-functioning lighting, cracked windows and water leaks (see also section 4.4). This makes it possible for the support function to make the necessary repairs without waiting for the ordinary users to report the faults. Other examples are implementing a helpdesk, introducing satisfaction surveys and use of social media in communication with users. 


\subsection{Strategic advice and planning}

Changing FM and CREM strategic advice and planning can be essential elements to support decisions in value adding management. The FM taxonomy (CEN, 2011) includes some products on strategic and tactical level, including a number of central functions with sub-products mentioned in parentheses:

- Sustainability (Life Cycle Planning/Engineering)

- Quality (Standards and Guidelines)

- Risk (Risk Policy)

- Identity (Innovation)

The areas for strategic advice and planning can cover many other aspects and they will typically change over time according to what is of strategic importance for the company. A typical area of strategic advice from FM/CREM to top management concerns the development of a long-term strategy for the corporate property portfolio. A clear insight in the demand for property and the provision of buildings, facilities and services that optimally fit with the changing demand requires a profound and up to date knowledge and understanding of the overall corporate strategy, careful ex-post and ex-ante evaluation of different options, scenario planning and proposals concerning the future supply of property. Research within CREM has resulted in a number of frameworks to support the development of strategies for property portfolios. The publication by De Jonge et al. (2009) includes a comparison of such frameworks and presents a generic framework for "Designing an Accommodation Strategy" (DAS-frame).

Another typical area is investment planning and feasibility studies, which concerns decision support on choosing between alternative options for fulfilling a need for changes in the capacity of space or similar. This can for instance be whether the company should extend existing facilities, relocate, build a new building, sell or buy property, rent or rent out space, etc. In these kinds of decisions it is often necessary to evaluate both the initial investment costs and the consequences for the continuous operational expenses. In such evaluations it can be useful to make calculations of Life Cycle Costing (LCC) - also called Whole Life Costing (ISO, 2017).

An example of strategic advice and planning is presented in case 6.

Case 6. Corporate Social Responsibility - CSR (Groen et al., 2017)

TNT Express is an international courier delivery services company, now a subsidiary of FedEx, with its headquarters in Hoofddorp, Netherlands. Given TNT's view that the interests of all stakeholders must need to be managed in a balanced way, TNT's annual reports should report on both financial and non-financial performance. The 2010 annual report is the first one that integrates CSR. As such, CSR performance and strategic performance must be the outcome of improved actions taken in day to day management of TNT's core business.

CSR is becoming increasingly important for large corporations. It is not typically an area of responsibility for FM/CREM, but FM and CREM can provide essential input both in terms of actions and reporting - not least concerning environmental impact. 
The 15 interventions concerning strategic advice and planning mentioned in interviews are listed in Table 10. It is notable that there are not many KPI's mentioned, which reflects that these interventions often are intangible and the output/outcome is difficult to measure.

Table 10. Interventions concerning strategic advice and planning mentioned in interviews

\begin{tabular}{|c|c|c|}
\hline Intervention & Prioritized value & KPIs \\
\hline $\begin{array}{l}\text { Closer collaboration between tenant } \\
\text { and real estate administration about } \\
\text { adapting offices to changes in } \\
\text { tenant's business activities. }\end{array}$ & $\begin{array}{l}\text { Coherent strategy } \\
\text { between core business } \\
\text { and FM }\end{array}$ & (Not mentioned) \\
\hline $\begin{array}{l}\text { Knowledge about how to create } \\
\text { well-being, safety and comfort for } \\
\text { staff }\end{array}$ & $\begin{array}{l}\text { Productivity of core } \\
\text { business }\end{array}$ & (Not mentioned) \\
\hline $\begin{array}{l}\text { Guideline for staff, when they move } \\
\text { in to a new tenancy. } \\
\text { Use of "cartoons" with drawings of } \\
\text { rebuilding projects. }\end{array}$ & Communication & (Not mentioned) \\
\hline Challenge the customer & $\begin{array}{l}\text { Improvements and } \\
\text { innovation }\end{array}$ & $\begin{array}{l}\text { Number of proposed } \\
\text { improvements and cost } \\
\text { reductions. } \\
\text { Innovation pools. }\end{array}$ \\
\hline Priority matrix & $\begin{array}{l}\text { Transparency of cost and } \\
\text { priorities }\end{array}$ & Cost \\
\hline $\begin{array}{l}\text { Site master plans / Space } \\
\text { Management }\end{array}$ & Scalability & Space utilisation \\
\hline $\begin{array}{l}\text { Be transparent in annual reports } \\
\text { (very important for shareholders) }\end{array}$ & $\begin{array}{l}\text { Transparency of real } \\
\text { estate }\end{array}$ & $\begin{array}{l}\text { Compliance. } \\
\text { Current obligations (e.g. } \\
\text { rent contracts). } \\
\text { Future liabilities. } \\
\end{array}$ \\
\hline $\begin{array}{l}\text { Interviews with staff about trends } \\
\text { and expected growth or } \\
\text { consolidation; if main trends are } \\
\text { known, then further investigation in } \\
\text { depth. }\end{array}$ & $\begin{array}{l}\text { Forecasting of future } \\
\text { needs }\end{array}$ & (Not mentioned) \\
\hline $\begin{array}{l}\text { Selling of corporate campus to } \\
\text { generate capital }\end{array}$ & $\begin{array}{l}\text { Right balance between } \\
\text { owned buildings and } \\
\text { rented buildings (in } \\
\text { connection to capital } \\
\text { needed for the } \\
\text { organisation) }\end{array}$ & (Not mentioned) \\
\hline $\begin{array}{l}\text { Analysis and high level exchange of } \\
\text { timely information on market needs } \\
\text { and expectations relevant to } \\
\text { successful application and }\end{array}$ & $\begin{array}{l}\text { Business’ strategic } \\
\text { acknowledgement of } \\
\text { market demand and }\end{array}$ & $\begin{array}{l}\text { Investments and cost } \\
\text { budgets targets and/or } \\
\text { shareholders value }\end{array}$ \\
\hline
\end{tabular}




\begin{tabular}{|c|c|c|}
\hline $\begin{array}{l}\text { operations of business } \\
\text { accommodation and facilities }\end{array}$ & $\begin{array}{l}\text { expectations which may } \\
\text { positively affect value }\end{array}$ & \\
\hline $\begin{array}{l}\text { Analyse and inform management of } \\
\text { accommodative and } \\
\text { operational/service level practical } \\
\text { consequences of user/tenants trends } \\
\text { and expectations } \\
\text { Provide recommendations } \\
\text { Change business' strategic focus on } \\
\text { space application and user/tenant } \\
\text { perspectives }\end{array}$ & User/tenant satisfaction & $\begin{array}{l}\text { Vacant/hired ratios } \\
\text { Hires turnover } \\
\text { Rent budgets targets }\end{array}$ \\
\hline $\begin{array}{l}\text { Long term/lifecycle planning and } \\
\text { sustainable operations, maintenance } \\
\text { and space developments, based on } \\
\text { analysis and confirmed trends. } \\
\text { Availability and adaptability of } \\
\text { service provision to changing needs }\end{array}$ & $\begin{array}{l}\text { Flexible and usability of } \\
\text { property/space for } \\
\text { different primary } \\
\text { (business) processes }\end{array}$ & $\begin{array}{l}\text { Scope and frequencies of } \\
\text { property condition analysis } \\
\text { Hires turnover }\end{array}$ \\
\hline $\begin{array}{l}\text { Overview of total occupancy cost } \\
\text { and income generated }\end{array}$ & Affordability & $\begin{array}{l}\text { Accommodation costs } / \mathrm{m}^{2} \\
\text { Total return } / \mathrm{m}^{2} \\
\text { Ratio of total occupancy } \\
\text { cost as percentage of total } \\
\text { income generated }\end{array}$ \\
\hline $\begin{array}{l}\text { Consistent and simple templates for } \\
\text { business case approvals } \\
\text { Dashboard Metrics } \\
\text { Progress Reports }\end{array}$ & $\begin{array}{l}\text { Speed of delivery and } \\
\text { problem solving }\end{array}$ & $\begin{array}{l}\text { Quarterly progress } \\
\text { reporting } \\
\text { Business case statistics } \\
\text { Percentage completed } \\
\text { capital investment projects } \\
\text { Deviation from targets on } \\
\text { programmes }\end{array}$ \\
\hline $\begin{array}{l}\text { Make complex databases, tools and } \\
\text { policies/procedures simpler and } \\
\text { easier to manage } \\
\text { Increase lease flexibility }\end{array}$ & $\begin{array}{l}\text { Increase clarity and risk } \\
\text { avoidance }\end{array}$ & $\begin{array}{l}\text { Three year listing lease } \\
\text { terminations/actions } \\
\text { Average lease duration } \\
\text { Lease database accuracy \% }\end{array}$ \\
\hline
\end{tabular}

\section{Discussion and conclusion}

The model for Value Adding Management presented in section 2 is based on the prerequisite that in order to create added value, FM and CREM need to make a change in the provision by implementing interventions. This means that just delivering routine provisions will not give the opportunity to create added value. This is in line with the original definition of FM in the European standard EN15221-1: "the integration of process within an organisation to maintain and develop the agreed services which support and improve the effectiveness of its primary activities" (CEN, 2006). Thus, FM can create value by maintaining services that support the core business, but to create added value FM has to develop the services and improve the effectiveness of the core business. 
The typology provides an overview of the different ways FM and CREM can add value and the cases and examples can be used as inspiration for developing specific interventions in practice. The typology is not necessarily complete. Other types of interventions to improve the performance of the organisation might exist. However, the typology is regarded to include the most important interventions in the current state of practice of FM and CREM. Various values are connected and not independent e.g. sustainability requires investments but can reduce costs.

In order to identify specific interventions, it is recommended to conduct a SWOT analysis of both the real estate portfolio and building related facilities and services and the organisation. Based on such an analysis, interventions that might result in quick wins can be investigated and decisions on which interventions to be prioritized can be made. Criteria for prioritization are the importance of the interventions (which interventions are most critical i.e. which gaps between desired and actual performance are most relevant to be coped with, regarding the needs and preferences of different stakeholders), urgency (what has to be done now, e.g. because of highly dissatisfied clients, customers or end users, or a misfit with current legislation), do-ability (affordability, opportunities and risks of application in the current building) and impact (benefits, costeffectiveness). For instance, in a factory business continuity is a highly ranked value. After an infection outbreak in a hospital and related negative publicity, increasing safety gets high priority (Van der Zwart et al., 2017). To select prioritized performance measures and KPIs out of a long list of possible KPIs a step-by-step plan may be helpful as has been suggested by Riratanaphong and Van der Voordt (2015).

Implementing interventions will make changes in the provision of FM/CREM and hopefully improve its performance. This is the output of FM/CREM. However, to create added value there is also a need for an improvement in outcome in terms of the overall organisational performance and possibly also of the surrounding environment. Only then can added value be created. In order to ensure that improvement in output is transformed into improvement in outcome, it is necessary that the implementation is managed in a proper and professional way. This involves that the FM/CREM interventions are aligned with the core business strategy and that stakeholders and relationships with external providers are managed well. Added value is subjective and perceived and expressed differently by different stakeholders. Thus, it is important to evaluate how different stakeholders experience the value adding. The essential criteria for added value are that the tradeoff between benefits and sacrifices is positive and that the outcome fulfils the organisational objectives.

In further research, it would be interesting to test and validate the typology on its outcomes and prioritization, which interventions fit best with what type of organization and the context, and to further develop the typology with other types of interventions. It could also be relevant to elaborate the other two elements - management and added value - in the Value Adding Management model, building on Jensen and Van der Voordt (2017) and Van der Voordt and Jensen (2018). 


\section{REFERENCES}

CEN (2006) Facility Management - Part 1: Terms and definitions. European Standard EN 152211. European Committee for Standardization.

CEN (2011) Facility Management - Part 4: Taxonomy of Facility Management - Classification and Structures. European Standard EN 15221-4. European Committee for Standardization.

Den Heijer, A. (2012) 'Linking Decisions and Performance: Adding Value Theories Applied to the University Campus’. Chapter 11 in: Jensen et al. (2012a), 177-194.

De Vries, J., De Jonge, H. and Van der Voordt, D.J.M. (2008) 'Impact of real estate interventions on organisational performance', Journal of Corporate Real Estate, 10 (3), 208-223.

De Jonge, H., Arkesteijn, M.H., Den Heijer, A.C., Vande Putte, H.J.M., De Vries, J.C. and Van der Zwart, J. (2009) Corporate Real Estate Management - Designing and Accommodation Strategy (DAS Frame). Teaching Compendium, Delft University of Technology.

Groen, B. (2014) 'Contribution of facility management to hospital(ity) issues'. Alexander (ed.) Proceedings of EFMC 2014, Berlin.

Groen, B., Vonk, M., Melissen, F. and Termaat, A. (2017) 'Corporate Social Responsibility. Chapter 16 in: Jensen et al. (2012a), 280-292 .

Hoendervanger, J.G., Van de Voordt, T., and Wijnja, J. (2012) Huisvestingsmanagement. Van strategie tot exploitatie. Groningen: Noordhoff Uitgevers.

ISO (2017) Buildings and constructed assets - Service life planning - Part 5: Whole life costing. International standard ISO15686-5. International Standardization Organization, Geneva, Switzerland.

Jensen, P.A. (2010) 'The Facilities Management Value Map: a conceptual framework', Facilities, $28(3 / 4), 175-188$.

Jensen, P.A. (2017) 'Strategic Sourcing and Procurement of Facilities Management Services', Journal of Global Operations and Strategic Sourcing, 10 (2), 138-158.

Jensen, P.A, and Katchamart, A. (2012) 'Value Adding Management: A Concept and a Case'. Chapter 10 in: Jensen et al. (2012a), 164-176.

Jensen, P.A. and Malmstrøm, O.E. (2012) 'The Start of a Nordic Focus on the Added Value of FM'. Chapter 2 in: Jensen et al. (2012a), 31-43. 
Jensen, P.A., Nielsen, K. and Nielsen, S.B. (2008) Facilities Management Best Practice in the Nordic Countries - 36 cases. Centre for Facilities Management - Realdania Research, DTU Management Engineering. Technical University of Denmark.

Jensen, P.A. and Van der Voordt, T. (eds) (2017) Facilities Management and Corporate Real Estate Management as Value Drivers: How to Manage and Measure Adding Value. Routledge, Oxfordshire, UK.

Jensen, P.A., Van der Voordt, T. and Coenen, C. (eds.) (2012a) The Added Value of Facilities Management - Concepts, Findings and Perspectives. Centre for Facilities Management Realdania Research, DTU Management Engineering, and Polyteknisk Forlag.

Jensen, P.A., Van der Voordt, T. and Coenen, C. and Sarasoja, A,-L. (2012b) 'Comparisons and Lesasons Learmed'. Chapter 17 in: Jensen et al. (2012a), 268-291.

Kaplan, R.S. and Norton, D.P. (2001) 'Having Trouble with your Strategy? Then Map It', Harvard Business Review, January-February 2001.

Lindholm, A-L. and Leväinen, K.I. (2006) 'A framework for identifying and measuring value added by corporate real estate’, Journal of Corporate Real Estate, 8 (1), 38-46.

Nardelli, G. (2017) 'Innovation Dialectics: An Extended Process Perspective on Innovation in Services', The Service Industries Journal, 37(1), 35-56.

Nardelli, G. and Broumels, M. (2018), 'Managing innovation processes through value co-creation: a process case from business-to-business service practise', The International Journal of Innovation Management, 22(3), 1850030.

Riratanaphong, C. and Van der Voordt, T. (2015) 'Measuring the added value of workplace Change', Facilities 33(11/12), 773-792.

Udawatta, C.S., Devapriya, K.A.K., Gowsiga, M. and Thatshayini, P. (2019) 'An investigation into value addition concept correlated to facilities management'. In: Sandanayake, Y.G., Gunatilake, S. and Waidyasekara, A. (eds.) Proceedings of the 8th World Construction Symposium, Colombo, Sri Lanka, 8-10 November 2019, 56-65.

Van der Voordt, T. (2017) 'Facilities Management and Corporate Real Estate Management: FM/CREM or FREM?' Journal of Facilities Management 15(3), 244-261.

Van der Voordt, D.J.M. and Jensen, P.A. (2014) 'Adding Value by FM: exploration of management practice in the Netherlands and Denmark'. In Alexander, K. (ed.) 'Promoting Innovation in FM'. Research Papers. Advancing knowledge in FM. International Journal of Facilities Management, EuroFM Journal. March 2014. 
Van der Voordt, T. and Jensen, P.A. (2018) 'Measurement and benchmarking of workplace performance: key issues in value adding management’, Journal of Corporate Real Estate, 20(3), 177-195.

Van der Voordt, T., Jensen, P.A., Hoendervanger, J.G. and Bergsma, F. (2016) 'Value Adding Management of buildings and facility services in four steps', Corporate Real Estate Journal, 6 (1), 42-56.

Van der Voordt, T., Prevosth, J. and Van der Zwart, J. (2012) 'Adding value by FM and CREM in Dutch Hospitals. Chapter 13 in Jensen et al. (2012a), 205-222. 